\title{
Yerel Medya Çalıșanlarının Eğitim Düzeyleri ve Mesleki Yeterlilikleri: Antalya Örneği ${ }^{1}$
}

\author{
Murad Karaduman ${ }^{2}$
}

\begin{abstract}
Öz
Türkiye'de iletişim fakültelerinin sayıları hızla artmasına karşın, bu artışın sektördeki karşılığı aynı oranda görülememektedir. Bu durum bir yandan ülkede iletişim eğitiminin sorgulanmasını gerektirirken diğer yandan ise sektörün iletişim fakültesi mezunlarına yaklaşımının sorgulanmasını da zorunlu hale getirmektedir. Zira sektörde "alaylı" olarak tabir edilen ve herhangi bir mesleki eğitim almaksızın mesleği icra ederken öğrenen kesimin ağırlığı sürmektedir. Çalışanlarını sınavla alan kurumlar da dâhil Türkiye'de neredeyse hiçbir medya kuruluşu, çalışan alırken iletişim fakültesi mezunlarına pozitif ayrım bağlamında kota koymamaktadır. Gazeteciliğin ve haberciliğin ciddi bir şekilde tartışıldığı, haber etiğinin bir kenara koyulduğu, haberlerde bilinçli veya bilinçsiz olarak yanlışların görüldüğü, bazı haberlerin yayına verilemediği günümüzde medya çalışanlarının eğitim ve mesleki yeterlilikleri çok önemli bir konudur. Gelişen iletişim teknolojileri ve değişen habercilik anlayışıyla birlikte günümüz habercisinin hem bilgi, hem de teknik yeterlilikler açısından donanımlı olması zorunluluk haline gelmiştir. Bu sorun ise kendini en çok, türlü zorluklarla yayın hayatını sürdürmeye çalışan yerel medya kurumlarında göstermektedir. Bu çalışma Antalya'da çeşitli medya kuruluşlarında (gazete, televizyon, dergi, radyo internet sitesi) farklı görevler yapan medya çalışanlarının eğitim düzeylerini ve mesleki yeterliliklerini ölçmeyi amaçlamaktadır. Çalışmada alan araştırması yöntemi kullanılacak ve araştırma verileri anket tekniğiyle toplanacaktır. Çalışma sonucunda Antalya kenti örneğinde yerel medya çalışanlarının eğitim düzeyleri ve yeterlilikleri saptanacak, buna bağlı sorunlar ortaya konacak, eksiklerin giderilmesi için öneriler sunulacaktır.
\end{abstract}

Anahtar Kelimeler: Gazetecilik, Medya, Mesleki Eğitim

\section{“Educational Level and Vocational Competencies of Local Media Employees: Antalya Case"}

\begin{abstract}
Despite the rapid increase in the number of communication faculties in the Turkish universities, the reflection of this increase cannot be observed in the sector. While the status quo requires an examination of education provided in communication in Turkey, it also leads us to question the approach of the sector towards the communication faculty graduates. Moreover, the sector continues to be dominated by those who did not receive any formal education related to communication but learned the

1 Erpa International Congresses of Education kongresinde "The level of training and vocational competencies of local media employees: The case of Antalya" başlığıyla sunulmuş ve İngilizce kısa versiyonu yayımlanmıştır.

2 Akdeniz Üniversitesi Illetişim Fakültesi, Yrd.Doç.Dr, mkaraduman@akdeniz.edu.tr
\end{abstract}


requirements of the industry while working in it. Almost none of the media organizations in Turkey, including those who recruit employees through oral or written exams, have contingency systems designed to ensure positive discrimination for the communication faculty graduates. In today's world, where journalism and the media are under a microscope, journalism ethics are pushed aside, news articles include a number of intentional and non-intentional mistakes and particular news is not even broadcast, the educational backgrounds and vocational competencies of the media employees are of great importance. With the development of communication technologies and the paradigm shift in journalism, today's reporters must have both knowledge and technical competencies at the same time to be able to work in the media sector. This issue is most pronouncedly experienced by local media organizations that encounter numerous difficulties while trying to sustain their activities. The purpose of this study is to measure the levels of education and vocational competencies of media employees working at various media organizations (newspapers, television channels, magazines, radios, websites) in Antalya, Turkey. The study is based on field researches and data will be gathered through a questionnaire. As a result of the study, the levels of education and competencies of local media employees in Antalya, Turkey will be identified, together with the issues experienced and there will also be some suggestions to overcome the deficiencies.

Keywords: Journalism, Media, Vocational Education 


\section{Giriș}

$\mathrm{T}$ ürkiye'de sayıları hızla artan iletişim fakülteleri gazetecilik, halkla ilişkiler ve tanıtım, radyo televizyon ve sinema, reklamcılık, yeni medya, görsel iletişim tasarımı gibi bölümleriyle eğitim vermektedir. Yükseköğretim Kurumu’ndan alınan bilgilere göre 1 Haziran 2015 tarihi itibariyle Türkiye toplam 66 iletişim fakültesinde, 50 gazetecilik bölümüyle eğitim verilmektedir. Gelişen iletişim teknolojileriyle birlikte iletişim ile haberleşmenin insan hayatındaki önemine paralel olarak iletişim fakültelerinin sayısının bu denli artması ilk bakışta hayatın doğal akışı olarak değerlendirilebilir (Gezgin, 2005). Ancak teknolojideki bu gelişmeler, iletişim ve medya sektörü açısından değerlendirildiğinde tam tersi bir etki yaratmakta ve istihdamın azalmasına neden olmaktadır (Yıldırım, 2006: 125). Gerek medyada, gerek iletişim sektöründe, gerekse sinema sektöründe ekonomik yapılar da gerekçe gösterilerek daha az çalışanla, daha fazla iş üretme anlayışı baskın bir biçimde egemen kılınmaktadır. Bunun sonucunda sektör daha ucuz iş gücü arayışına girmekte ve iletişim fakültesi mezunu olsun olmasın yeterli kalifikasyona sahip olmayan çalışanlar tercih edilmektedir. Bu durum iki farklı sakınca ortaya koymaktadır: Birincisi sektörde yeterli bilgi, birikim ve donanıma sahip olmayan, iş bilmeyen, işi yaptıkça öğrenen çalışanlar tabiri caizse işin hamallığını yaparak sektörü ayakta tutmaktadır (Tokgöz, 2003: 12). İkincisi her yıl binlerce iletişim fakültesi mezununun büyük bölümü ya işsiz kalmakta ya da ilgili-ilgisiz farklı sektörlere yönelmektedir. İletişim Fakültesi mezunlarından garson, aşçı, polis, bankacı, özel güvenlik görevlisi, satış temsilcisi, rehber, turizmci, sekreter gibi çok farklı sektörlerde çok farklı görevler yapan çalışanlar bulunmaktadır. Belki bu iki soruna ek olarak, sektörde fakülte mezunlarına karșı bu ilgisizlik ve özensizliğin sonucunda öğrencilerin umutsuzluğa kapılmaları ve nasıl olsa sektöre kabul edilmeyecekleri ya da düşük ücret ve kötü şartlarda çalıştırılacakları düşüncesiyle eğitimlerini aksatarak yeterli donanıma sahip olmadan mezun olmaya çalışmaları da eklenebilir.

İletişim alanında sektörü ve üniversite eğitimini bu şekilde değerlendirmekle birlikte çalışmamızın ana konusu sektörde çalışan kişilerin eğitim, bilgi ve birikimlerini ölçmeye yöneliktir (Korkmaz, 2012: 14). Belirttiğimiz sorunlar Türkiye'de özellikle olması gereken güçte olmayan, ekonomik, siyasi ve türlü baskılarla yayın hayatlarını sürdürmeye çalışan yerel medya kurumlarında daha sıklıkla yaşanmaktadır. Bu nedenle çalışmada Antalya yerel medyasında çalışan gazetecilerin eğitim, bilgi, birikim ve çalışma koşullarına odaklanılmıştır.

\section{Yerel Medyanın Önemi}

Osmanlı'da İlk Türkçe gazete olan Takvim-i Vekâyi, Osmanlı'da 1831 yılında II. Mahmut'un fermanıyla yayın hayatına başlamıştır. 1831 'den sonra, basın, ülke içinde geniş anlamda yaygınlaşmaya başlamış ve 19. yüzyılın sonlarına doğru da bugünkü anlamıyla yerel gazete olarak tanımlanan vilayet gazeteleri oluşmuştur (Dağtaş ve Dağtaş, 2007: s. 15). O günden bu yana yerel gazeteler Türkiye'de hem siyaset ve toplumun etkilerine, hem de medya sektöründeki yeniliklere paralel olarak gelişim ve değişim göstermektedir.

Yeni medyayı bir tarafa bırakacak olursak; medya deyimi genel olarak gazeteler, dergiler, radyolar ve televizyonları kapsar. Bu araçlar kitle iletişim araçları olarak 
tanımlansa da, erişebildikleri kitlelerin büyüklüğüne göre bu araçlar da kendi aralarında sınıflandırılırlar. Genellikle bir ülkede faaliyet gösteren medya kuruluştan yayıldıkları alan ya da hitap ettikleri kitlelerin coğrafi dağılımları göz önünde bulundurularak ulusal, bölgesel ve yerel olmak üzere üçe ayrılırlar. Bu üç sınıflama kapsamında değerlendirilebilecek medya kuruluştan şöyle tanımlanabilir:

-Ulusal medya: Tek bir basım-yayın kuruluşu tarafından aynı isimle basılan ya da yayınlanan ve ülkenin en az \% 70'inde dağıtılan ya da izlenen gazete, dergi, bülten, radyo ve televizyon yayınlarını ve bunları yapan kuruluşları kapsar.

-Bölgesel medya: Tek bir basın-yayım kuruluşu tarafından aynı isimle basılan ya da yayınlanan ve üç komşu ilde veya en az bir coğrafi bölgede dağıtılan ya da izlenen gazete, dergi, bülten, radyo ve televizyon yayınlarını ve bunları yapan kuruluşları kapsar.

-Yerel medya: Tek bir basım-yayın kuruluşu tarafından aynı isimle tek bir yerleşim biriminde basılan ya da yayınlanan ve yalnızca o yerleşim biriminde dağıtılan ya da izlenen gazete, dergi, bülten, radyo ve televizyon yayınlarını ve bunları yapan kuruluşları kapsar (Altun, 2005: 79).

Yöre halkını bilgilendirmeye, eğitmeye, eğlendirmeye, o bölgede kamuoyunun oluşumunu sağlamaya yönelik yayıncılık faaliyeti içinde bulunan, bölge halkının iletişim kurumu özelliği taşıyan kitle iletişim aracı ya da araçların tümüne yerel medya denmektedir. Yerel medya, Türk tarihinde farklı isimler almıştır. Özellikle Kurtuluş Savaşında, Milli Mücadele'yi topluma duyurmakla görevli olan yerel basın, o dönemde "Anadolu Basını" veya "Taşra Basını" olarak adlandırılmıştır. Bir bölgede gündemin, haberin ne olduğu veya ne olması gerektiğinin bilinmesi o yöre halkı için çok önemlidir. Bu açıdan bakıldığında da son yıllarda, hızıı bir gelişim gösteren yerel medya olgusu ve yerel medyanın işlevleri giderek önem kazanmaktadır (Temel, Korkmaz ve diğerleri, 2012: 127). Bugünün küresel dünyasında yerelliğin değeri ve önemi artmıştır, artmaya devam edecektir.

Yerel gazeteler, çıktıkları ilk zamanlardan beri toplumda, çok önemli işlevler üstlenmişlerdir. Bu gazeteler o kentin bütün sorunları içinde yoğrulmakta ve okurgazete ilişkisi, çoğu kez aile yakınlığı ve ilişkileri boyutlarına kadar varmaktadır. Bu nedenle yerel basın çeşitli ülkelerde, değişik etkenler nedeniyle doğup gelişmiştir (Değirmencioğlu, 2011: 19).

Yerel yönetimler ve yerinden yönetim birimlerinin denetlenmesi, bölgesel sorunların ve yerel taleplerin kamuoyunda tartışıımasını sağlaması açısından yerel gazetelerin bilgilendirme ve yerel alternatif gündemler oluşturma işlevleri önemsenmektedir. Gazete içeriklerinin yaygın basında haber ajansları ve ulusal önem sırasına göre belirlenmesi yerel talep ve sorunların kendilerine gazete içeriklerinde yer bulamamalarına neden olmaktadır. Bu eksikliğin giderilmesi yerel veya bölgesel sorun, talep ve gündemlerin okuyucu kitlesine taşınması yerel basın kuruluşları kanalıyla gerçekleşebilir. Bu yönüyle yaygın veya ulusal basının bir alternatifi değil tamamlayıcısıdır. Yaygın basın kuruluşlarının bölge sayfaları bu ihtiyaçtan doğmuştur (Yaşın, 2009: 116).

Yerel basın, yayımladığı haberler, fotoğraflar, ele aldığı sorunlar, kentin gereksinimleri, 
kentteki kültürel ve sosyal etkinliklere ilişkin aktardığı bilgilerle bireye "yaşanan yer" duygusunu, yaşadığı yerin bir parçası olduğu düşüncesini kazandırmaktadır. Bu nedenlerle hemen hemen tüm gelişmiş ve gelişmekte olan ülkelerde, kitle iletişim araçları iki yönlü bir ilerleme süreci içine girmişlerdir. Bir bölümüyle sınırları aşan bir bütünleşme süreci yaşanmakta; öte yandan da hemen hemen her kent, her kasaba, hatta her semt, her mahalle yerel gazeteye, radyoya sahip olmak istemektedir (Vural, 1996: 1054). Bu adeta kentler için bir ihtiyaç haline gelmiştir.

Tüm bunlara ek olarak kent bilinci ile kent kültürü oluşumu ve gelişiminde yerel medyanın rolü önemlidir. Yerel medya kent kültürünün ana taşıyıcılarından birisi konumundadır.

\section{Yerel Medya Çalıșanlarının Sorunları}

Yerel medya çalışanlarının yeterliliklerini sorgulamadan önce çalışma şartları ve sorunlarını da ele almak gereklidir. Yerel medya çalışanlarının sorunlarını, medya çalışanlarının sorunlarından tam olarak ayırmak mümkün görünmüyor olsa bile, yerel medyanın kendine özgü koşullarından dolayı yerel medya çalışanlarının karşı karşıya olduğu farklı sorunlar da görülmektedir.

Türkiye'deki yerel yayıncılık sektöründe ve özelinde yerel gazetelerde bazı önemli sorunlar göze çarpmaktadır. Bundaki en önemli faktörün yerel gazetelerin ekonomipolitik durumu olduğu düşünülmektedir. Ekonomi politik yaklaşım, egemen yaklaşım tarafından görmezden gelinen iktisadi, siyasi ve ideolojik mekanizmaların görünebilir olması gerektiğini savunan bir yaklaşımdır. Bu yaklaşım ayrıca, söz konusu mekanizmaların, sınıf, kapitalist üretim ilişkileri, kapitalizmin eşitsiz gelişme yasası ve uluslararası iş bölümü kavramlarının analize dâhil edilmesi gerekliliğini savunmaktadır (Toruk ve Olkun, 2014: s. 380).

Türkiye'de yerel yayıncılık ve yerel medya bu bağlamda ele alındığında siyaset ve sermayeyle olan ilişikleri, bu ilişkilerin haber üretim süreçlerine etkileri, dağıtım kanallarının sınırlılığı, ekonomik sorunlar ve bunların yansımaları ile etik sorunlar ön plana çıkmaktadır.

Yerel basın, yaygın basına göre daha dar bir hedef kitlesi olan, il, ilçe ve beldelerde günlük, haftalık ya da aylık yayınlanan ve çoğunlukla yayınlandığı bölgenin haberlerine yer veren basındır. Yerel gündemdeki konulara öncelik veren ve yerel sorunları ön planda tutan yerel basın, yayımlandığı yöredeki yerel kamuoyuna yönelik faaliyetler gerçekleştirmektedir. Dolayısıyla yerel basın bölgesel sorunlar üzerinde etkindir ve sorunların yerinde çözümü açısından da önemlidir (Yılmaz, 2009: 136). Basit bir anlatımla; herkesin kendi sokağında meydana gelen, ülkenin ya da dünyanın diğer yerlerinde meydana gelen benzer şeylerden daha önemlidir. Eğer sokağında yaşadığı bir sorun varsa önce onun çözülmesini bekler.

Çalışanlar açısından baktığımızda ise yerel basın habercilik mesleğinin en iyi öğrenebileceği ve etik değerlerin en yüksek standartlarda uygulanabileceği alandır. Haber kaynağına ve okura-izleyiciye mesafenin yakınlığı buradaki en önemli etkendir. Hem haber kaynağı gazeteci açısından kolay ulaşılabilirdir; hem de gazeteci okur- 
izleyici tarafından kolay ulaşılabilirdir. Gazeteci-haber kaynağı-okur arasındaki mesafe ve dolayısıyla iletişimsel yakınlık yerel haberciliğin temelidir.

Gazetecilik meslek etiğinde ortaya çıkan sorunları gazetecinin maddi çıkarlarını öncelikli olarak düşünmesinden, medyanın mülkiyet yapısına; gazetecinin mesleki alandaki eğitim eksikliğinden, toplumsal dejenerasyona kadar geniş bir perspektifte değerlendirmek olanaklıdır. Tüm sorunları alt alta sıraladığımızda meslek etiğindeki sorunları ortaya çıkaran faktörleri; gazetecilerden kaynaklı 'içsel' ve ortamdan kaynaklanan 'dışsal' faktörler olarak iki başlıkta toplayabilmek olanaklıdır. Bu tür sorunlar yerel ve ulusal gazeteciler için ortak sorunlar olarak kabul edilebilir. Bu faktörler ise özlüce tablo 1'de ortaya koyulmaya çalışılmıştır (Arslan ve Arslan, 2016: 183).

Tablo 1: Gazetecilikteki etik sorunlara ilişkin temel faktörler

\begin{tabular}{|c|c|}
\hline $\begin{array}{c}\text { İçsel Faktörler } \\
\text { (Gazeteciden kaynaklı) }\end{array}$ & $\begin{array}{l}\text { Dișsal Faktörler } \\
\text { (Ortamdan kaynaklı) }\end{array}$ \\
\hline Kișisel çıkarların ön planda tutulması & Medyanın mülkiyet yapısından kaynaklanan sorunlar \\
\hline Haberlerden maddi çıkar sağlamak & Medya sahibinin tutumu \\
\hline Etnosentrik bakıș açısı & Tiraj ve reklam -ilan baskısı \\
\hline Haberde doğruluk & Okur temsilciliği/ombudsmanlık sisteminin yetersizliği \\
\hline Eleștiri sınırının așılması & Haber kaynaklarının etkisi \\
\hline Eğitim eksikliği & Toplumsal bozulma \\
\hline $\begin{array}{l}\text { Hediyelere, gezilere ve ayrıcalık tanımalara prim } \\
\text { vermek }\end{array}$ & Medya kurumunun yayın politikası \\
\hline Haber-yorum ayrımın yapııması & $\begin{array}{l}\text { Meslek örgütlerinin uygulama ve yaptıımlardak } \\
\text { yetersizliği }\end{array}$ \\
\hline
\end{tabular}

Bunların dışında yerel medya çalışanları çok düşük maaşlarla, bazı yerlerde sosyal güvencesi olmadan çalıştırılmaktadır. Hatta buralardaki gazeteciler genellikle ikinci iş yapmak zorunda kalabilmektedir. Hâlbuki yerel basında çalışan bir gazeteci ile ulusal basında çalışan bir gazeteci arasında temelde hiçbir fark yoktur. Gazetecinin görevi, işlevi ve mesleki sorumlulukları aynıdır. Ancak maalesef, yerel basının eleman yetersizliği, çalışanlarının kalifiye olmayan elemanlardan oluşması; haber çeşitliliğinin sınırlı kalmasına, inceleme-araştırma haberlerinin ve köşe yazılarının sayıca az olmasına, diğer bir deyişle gazetenin içeriğinin az olmasına sebep olmaktadır. Bu tür gazete veya yayın kuruluşlarının çoğunluğu Basın İlan Kurumu’ndan gelen belirli miktarda resmi ilanların getirisiyle ayakta durabilmektedir. Okuyucuya satıştan elde edilen elde edilen gelir de tirajın son derece düşük miktarlarda kalmasından dolayı oldukça düşüktür (Ulusoy, 2003: 105).

Özlük haklarıyla ilgili sorunların yanısıra mesleğin icrasıyla ilgili sıkıntılar da mevcuttur. Yukarıda bahsettiğimiz, doğru ve etik habercilik açısından önemi vurgulanan mesafe yakınlığı, zaman zaman zorlukları da beraberinde getirebilir. Çeşitli baskı ve tehditler, yerel medya çalışanları için daha fazla hissedilir olabilir. 


\section{Yöntem}

Çalışmamızın ilk bölümünde yerel medya kavramsal olarak açıklanmış ve çalışanlarının durum ve sorunları ele alınmıştır. Her meslek çalışanının olduğu gibi yerel medya çalışanlarının da görev, hak ve sorumlulukları bulunmaktadır. Gazetecilik mesleğini doğru ve iyi bir biçimde yapabilmeleri için de aldıkları eğitimin önemi büyüktür. Bu çalışma Antalya'da yerel medya çalışanlarının eğitim ve mesleki yeterliliklerine yönelik bir durum tespiti yapmayı amaçlamaktadır. Çalışmanın araştırma sorusu şu şekildedir: Antalya merkezde görev yapan yerel medya çalışanlarının eğitim ve mesleki yeterlilik düzeyleri nedir? Çalışmada alan araştırması yöntemi kullanıımış ve araştırma verileri anket tekniğiyle toplanmıştır. Anket formunda yer alan sorularda anlaşılamayan ifadelerin düzenlenmesi amacıyla kolayda örnekleme yöntemi ile belirlenen 15 gazeteci ile bir ön test gerçekleştirilmiştir. Ön testin ardından küçük düzeltmelerle anket son halini almıştır. Çalışma kapsamında 150 akredite gazetecinin çalıştığı Antalya yerel medyasında, 73 gazeteciye bu anket uygulanmıştır. Araştırmanın varsayımı Antalya yerel medyasında çalışan gazetecilerin mesleki eğitim ve mesleki bilgi düzeylerinin yeterli olmadığıdır. Araştırmanın sınırlılığı 150 gazeteciden 73'üne ulaşılmış olmasıdır. Anket soruları özgündür. Elde edilen veriler, SPSS veri analiz programında analiz edilmiştir.

\section{Bulgular}

Tablo 2: Cinsiyetiniz?

\begin{tabular}{|l|c|c|}
\hline \multicolumn{3}{|c|}{ Cinsiyetiniz? } \\
\hline & Sayı & $\%$ \\
\hline Erkek & 42 & 57,5 \\
\hline Kadın & 31 & 42,5 \\
\hline Toplam & 73 & 100,0 \\
\hline
\end{tabular}

Araştırmaya katılanların yüzde 57,5’i erkek, yüzde 42,5’i kadın gazetecilerden oluşmaktadır.

Tablo 3: Yaşınız?

\begin{tabular}{|l|c|c|}
\hline \multicolumn{2}{|c|}{ Yașını? } \\
\hline & Sayı & $\%$ \\
\hline $18-25$ arası & 19 & 26,0 \\
\hline $26-35$ arası & 38 & 52,1 \\
\hline $36-45$ arası & 13 & 17,8 \\
\hline $46-55$ arası & 3 & 4,1 \\
\hline 56 ve fazlası & 0 & 0 \\
\hline Toplam & 73 & 100,0 \\
\hline
\end{tabular}


Katılımcıların yüzde 52,1'i 26-35, yüzde 26'sı 18-25, yüzde 17,8'i 36-45, yüzde 4,1'i de 46-55 yaş aralığında bulunmaktadır. Bu sonuçlardan Antalya yerel medyasında genç bir nüfusun çalıştığı ortaya çıkmaktadır. Diğer taraftan bu sonuç meslekte deneyim kazanan gazetecilerin sektör dışına yöneldiği şeklinde de okunabilir.

Tablo 4: Eğitim durumunuz?

\begin{tabular}{|l|c|c|}
\hline \multicolumn{3}{|c|}{ Eğitim durumunuz? } \\
\hline & Sayı & $\%$ \\
\hline İlköğretim & 0 & 0 \\
\hline Lise & 21 & 28,8 \\
\hline Ön lisans & 9 & 12,3 \\
\hline Lisans & 41 & 56,2 \\
\hline Lisansüstü & 2 & 2,7 \\
\hline Toplam & 73 & 100,0 \\
\hline
\end{tabular}

Araştırmaya katılanların yüzde 56,2'si lisans, yüzde 28,8'i lise, yüzde 12,3'ü ön lisans, yüzde 2,7'si de lisansüstü mezunudur.

Tablo 5: Iletişim Fakültesi mezunu musunuz?

\begin{tabular}{|l|c|c|}
\hline \multicolumn{3}{|c|}{ Iletișim Fakültesi mezunu musunuz? } \\
\hline & Sayı & $\%$ \\
\hline Evet & 26 & 35,6 \\
\hline Hayır & 16 & 21,9 \\
\hline Boș & 31 & 42,5 \\
\hline Toplam & 73 & 100,0 \\
\hline
\end{tabular}

Katılımcıların sadece yüzde 35,6'sı İletişim Fakültesi mezunudur. Antalya'da 15 yıldır eğitim ve yüzlerce mezun veren Akdeniz Üniversitesi İletişim Fakültesi, Türkiye'deki diğer iletişim fakültesinden mezun olup Antalya'da çalışan mezunlarla birlikte yerel medyada yalnızca yüzde 35,6 oranında temsil edilmektedir.

Tablo 6: Kurumunuzdaki pozisyonunuz?

\begin{tabular}{|l|c|c|}
\hline \multicolumn{3}{|c|}{ Kurumunuzdaki pozisyonunuz? } \\
\hline & Sayı & $\%$ \\
\hline Muhabir & 35 & 47,9 \\
\hline Yazı ișleri & 9 & 12,3 \\
\hline Genel yayın yönetmeni & 7 & 9,6 \\
\hline Sayfa sekreteri & 7 & 9,6 \\
\hline Kameraman & 3 & 4,1 \\
\hline
\end{tabular}




\begin{tabular}{|l|c|c|}
\hline Haber șefi & 2 & 2,7 \\
\hline Haber spikeri & 1 & 1,4 \\
\hline Toplam & 64 & 87,7 \\
\hline Boș & 9 & 12,3 \\
\hline Toplam & 73 & 100,0 \\
\hline
\end{tabular}

Katılımcıların çoğunluğu muhabir pozisyonunda çalışmaktadır. (yüzde 47,9) Yüzde 31,5 ’ de editoryal kadroda yer almaktadır.(Genel yayın yönetmeni, sayfa sekreteri, yazı işleri).

Tablo 7: Aylık geliriniz?

\begin{tabular}{|l|c|c|}
\hline \multicolumn{3}{|c|}{ Aylk geliriniz? } \\
\hline & Sayı & $\%$ \\
\hline <999TL & 16 & 21,9 \\
\hline $1000-1500$ & 26 & 35,6 \\
\hline $1501-2000$ & 12 & 16,4 \\
\hline $2001-2500$ & 7 & 9,6 \\
\hline $2501-3000$ & 8 & 11,0 \\
\hline 3001-5000 & 1 & 1,4 \\
\hline $5000 T$ 'den az & 1 & 1,4 \\
\hline Toplam & 71 & 97,3 \\
\hline Boș & 2 & 2,7 \\
\hline Toplam & 73 & 100,0 \\
\hline
\end{tabular}

Antalya il ölçeğinde 2015 yılında gerçekleştirilen araştırmada gazetecilerin yüzde 21,9'unun 1000 TL'den az maaşla çalıştığı görülmektedir. Yüzde 35,6'sı bin ila bin 500 TL arasında maaş almakta, yüzde 37'si ise 1550 ila 3000 maaş almaktadır. 3000TL üzeri maaş alanların yüzdesi oldukça düşüktür (yüzde 2,8). Bu iki sonuç birlikte okunduğunda Antalya yerel medyasında çalışanların ağırlıklı olarak 1500TL altı ücretlerle görev yaptığı anlaşılmaktadır.

Tablo 8: Kaç yıldır bu meslekte çalışmaktasınız?

\begin{tabular}{|l|c|c|}
\hline \multicolumn{3}{|c|}{ Kaç yıldır bu meslekte çalıșmaktasınız? } \\
\hline & Sayı & $\%$ \\
\hline $0-5$ & 33 & 45,2 \\
\hline $6-10$ & 16 & 21,9 \\
\hline $11-15$ & 7 & 9,6 \\
\hline $16-20$ & 7 & 9,6 \\
\hline $21-25$ & 4 & 5,5 \\
\hline
\end{tabular}




\begin{tabular}{|l|c|c|}
\hline $26-30$ & 2 & 2,7 \\
\hline $31-35$ & 0 & 0 \\
\hline Boș & 4 & 5,5 \\
\hline Toplam & 73 & 100,0 \\
\hline
\end{tabular}

Gazetecilerin yüzde 45,2'si 0-5 yıldır, yüzde 21,9'u 6 ila 10 yıl arası, yüzde 27,4'ü ise 10 yıldan fazla süredir bu mesleği yapmaktadır.

Tablo 9: Kaç yıldır Antalya'da çalışmaktasınız?

\begin{tabular}{|l|c|c|}
\hline \multicolumn{3}{|c|}{ Kaç yldır Antalyáda çalıșmaktasııı? } \\
\hline & Sayı & $\%$ \\
\hline $0-5$ & 40 & 54,8 \\
\hline $6-10$ & 11 & 15,1 \\
\hline $11-15$ & 8 & 11,0 \\
\hline $16-20$ & 6 & 8,2 \\
\hline $21-25$ & 2 & 2,7 \\
\hline $26-30$ & 1 & 1,4 \\
\hline $31-35$ & 0 & 0 \\
\hline Boș & 5 & 6,8 \\
\hline Toplam & 73 & 100,0 \\
\hline
\end{tabular}

Katılımcı gazetecilerin yüzde 54,8'i 0-5 yıldır, yüzde 15,1'i 6 ila 10 yıldır, yüzde 23,3'ü ise 10 yıldan fazla süredir Antalya'da çalışmaktadır.

Tablo 10: Çalışı̆̆ınız kurum?

\begin{tabular}{|l|c|c|}
\hline \multicolumn{3}{|c|}{ Calıștığınız medya kurumu? } \\
\hline & Sayı & $\%$ \\
\hline Gazete & 47 & 64,4 \\
\hline Dergi & 2 & 2,7 \\
\hline İnternet gazetesi & 4 & 5,5 \\
\hline Haber ajansı & 10 & 13,7 \\
\hline Televizyon & 9 & 12,3 \\
\hline Boș & 1 & 1,4 \\
\hline Toplam & 73 & 100,0 \\
\hline
\end{tabular}

Katılımcıların yüzde 64,4'ü gazetede, yüzde 13,7'si haber ajansında, yüzde 12,3'ü televizyonda, yüzde 5,5’i internet gazetesinde, yüzde 2,7'si de dergide çalışmaktadır. 
Tablo 11: Haftada ortalama kaç saat çalışıyorsunuz?

\begin{tabular}{|l|c|c|}
\hline \multicolumn{3}{|c|}{ Haftada ortalama kaç saat çalıșıyorsunuz: } \\
\hline & Sayı & $\%$ \\
\hline 40 saatten az & 1 & 1,4 \\
\hline $40-49$ saat & 25 & 34,2 \\
\hline $50-59$ saat & 17 & 23,3 \\
\hline $60-69$ saat & 13 & 17,8 \\
\hline $70-79$ saat & 10 & 13,7 \\
\hline 80 saatten fazla & 7 & 9,6 \\
\hline Toplam & 73 & 100,0 \\
\hline
\end{tabular}

Gazetecilerin yüzde 34,2'si haftada ortalama 40 ila 49 saat arasında, yüzde 23,3'ü 50 ila 59 saat, yüzde 41,1 'i de haftada ortalama 60 saat ve üzeri çalışmaktadır. Basın İş Kanunu'na göre gazetecilerin haftalık çalışma saati günlük 8 saatten toplam 48 saattir. Bu saatin üstünün ek mesai olarak değerlendirilmesi gerekir. Görüldüğü üzere Antalya medya çalışanlarının yaklaşık yüzde 65’i bu normal sürenin üstünde çalıştırılmaktadır. Çalışanların yüzde 9,6 gibi önemli bir kısmı da haftada 80 saatin üstü gibi insanüstü bir şekilde çalıştığını belirtmesi kayda değerdir.

Tablo 12: Yabancı dil bilgisi

\begin{tabular}{|l|c|c|}
\hline \multicolumn{3}{|c|}{ Yabancı dil bilgisi } \\
\hline & Sayı & $\%$ \\
\hline Evet & 8 & 11,0 \\
\hline Hayır & 65 & 89,0 \\
\hline Toplam & 73 & 100,0 \\
\hline
\end{tabular}

Tablo 13: Yabancı dil düzeyi

\begin{tabular}{|c|c|c|c|c|c|c|c|c|c|c|c|c|c|c|}
\hline \multirow{2}{*}{$\begin{array}{l}\text { Yabancı } \\
\text { dil düzeyi }\end{array}$} & \multicolumn{2}{|c|}{ Çok iyi } & \multicolumn{2}{|l|}{ İyi } & \multicolumn{2}{|c|}{ Orta } & \multicolumn{2}{|l|}{$\mathrm{Az}$} & \multicolumn{2}{|c|}{ Çok az } & \multicolumn{2}{|l|}{ Boș } & \multicolumn{2}{|c|}{ Top. } \\
\hline & $S$ & $\%$ & $S$ & $\%$ & $S$ & $\%$ & $S$ & $\%$ & $S$ & $\%$ & $S$ & $\%$ & $S$ & $\%$ \\
\hline İngilizce & 4 & 6,8 & 12 & 16,4 & 34 & 46,6 & 10 & 13,7 & 1 & 1,4 & 11 & 15,1 & 73 & 100 \\
\hline Almanca & 2 & 2,7 & 4 & 5,5 & 3 & 4,1 & 0 & 0 & 0 & 0 & 64 & 87,7 & 73 & 100 \\
\hline Fransizca & 1 & 1,4 & 0 & 0 & 0 & 0 & 0 & 0 & 0 & 0 & 72 & 98,6 & 73 & 100 \\
\hline Rusça & 0 & 0 & 1 & 1,4 & 2 & 2,7 & 0 & 0 & 0 & 0 & 70 & 95,9 & 73 & 100 \\
\hline Arapça & 1 & 1,4 & 0 & 0 & 0 & 0 & 1 & 1,4 & 1 & 1,4 & 70 & 95,9 & 73 & 100 \\
\hline Diğer & 0 & 0 & 0 & 0 & 1 & 1,4 & 0 & 0 & 0 & 0 & 72 & 98,6 & 73 & 100 \\
\hline
\end{tabular}

Antalya yazılı ve görsel basınında çalışanların yüzde 89'u yabancı dil bilmediğini ifade etmektedir. Yabancı dil bilenlerin yüzde 5,8'i İngilizce, yüzde 2'si Almanca, yüzde 2'si 
Fransızca, yüzde 1,2'si ise Arapça bilmektedir. Antalya gibi bir turizm bölgesinde bu medya çalışanlarının çok büyük çoğunluğu yabancı dil bilmemektedir.

Tablo 14: Kullandığınız bilgisayar programları

\begin{tabular}{|c|c|c|c|c|c|c|c|c|c|c|c|c|c|c|}
\hline \multirow{2}{*}{$\begin{array}{l}\text { Kullandığınız } \\
\text { bilgisayar } \\
\text { programları }\end{array}$} & \multicolumn{2}{|c|}{ Çok iyi } & \multicolumn{2}{|l|}{ İyi } & \multicolumn{2}{|c|}{ Orta } & \multicolumn{2}{|l|}{$\mathrm{Az}$} & \multicolumn{2}{|c|}{ Çok az } & \multicolumn{2}{|l|}{ Boș } & \multicolumn{2}{|c|}{ Top. } \\
\hline & $S$ & $\%$ & $S$ & $\%$ & $S$ & $\%$ & $S$ & $\%$ & $S$ & $\%$ & $S$ & $\%$ & $S$ & $\%$ \\
\hline Microsoft Office & 38 & 52,1 & 25 & 34,2 & 4 & 5,5 & 0 & 0 & 0 & 0 & 6 & 8,2 & 73 & 100 \\
\hline AdobePhotoshop & 17 & 23,3 & 21 & 28,8 & 17 & 23,3 & 7 & 9,6 & 0 & 0 & 11 & 15,1 & 73 & 100 \\
\hline AdobeFreehand & 3 & 4,1 & 2 & 2,7 & 5 & 6,8 & 0 & 0 & 1 & 1,4 & 61 & 83,6 & 73 & 100 \\
\hline Adobelndesign & 8 & 11,0 & 4 & 5,5 & 7 & 9,6 & 2 & 2,7 & 1 & 1,4 & 51 & 69,9 & 73 & 100 \\
\hline AdobeDreamwiever & 1 & 1,4 & 1 & 1,4 & 5 & 5,5 & 1 & 1,4 & 2 & 2,7 & 64 & 87,7 & 73 & 100 \\
\hline Quarkxpress & 10 & 13,7 & 4 & 5,5 & 7 & 9,6 & 2 & 2,7 & 0 & 0 & 50 & 68,5 & 73 & 100 \\
\hline Corel Draw & 4 & 5,5 & 0 & 0 & 5 & 6,8 & 0 & 0 & 2 & 2,7 & 62 & 84,9 & 73 & 100 \\
\hline Adobeillustrator & 6 & 8,2 & 2 & 2,7 & 2 & 2,7 & 0 & 0 & 2 & 2,7 & 61 & 83,6 & 73 & 100 \\
\hline Sicrubus & 0 & 0 & 0 & 0 & 0 & 0 & 0 & 0 & 4 & 5,5 & 69 & 94,5 & 73 & 100 \\
\hline AdobePremiere & 2 & 2,7 & 5 & 6,8 & 2 & 2,7 & 0 & 0 & 2 & 2,7 & 62 & 84,9 & 73 & 100 \\
\hline Edius & 10 & 13,7 & 7 & 9,6 & 7 & 9,6 & 3 & 4,1 & 2 & 2,7 & 44 & 60,3 & 73 & 100 \\
\hline AfterEffect & 3 & 4,1 & 4 & 5,5 & 1 & 1,4 & 3 & 4,1 & 3 & 4,1 & 59 & 80,8 & 73 & 100 \\
\hline Final Cut & 0 & 0 & 2 & 2,7 & 1 & 1,4 & 0 & 0 & 3 & 4,1 & 67 & 91,8 & 73 & 100 \\
\hline Avid & 0 & 0 & 0 & 0 & 0 & 0 & 0 & 0 & 4 & 5,5 & 69 & 94,5 & 73 & 100 \\
\hline Corel Video Studyo & 2 & 2,7 & 2 & 2,7 & 1 & 1,4 & 1 & 1,4 & 3 & 4,1 & 64 & 87,7 & 73 & 100 \\
\hline Sony Vegas Pro & 0 & 0 & 0 & 0 & 1 & 1,4 & 0 & 0 & 4 & 5,5 & 68 & 93,2 & 73 & 100 \\
\hline Diğer; yazınız & 2 & 2,7 & 0 & 0 & 0 & 0 & 0 & 0 & 0 & 0 & 71 & 97,3 & 73 & 100 \\
\hline
\end{tabular}

Medya sektöründe özellikle tasarım ve kurgu alanlarında farklı bilgisayar programlarının kullanımı giderek artmaktadır. Katılımcıların yüzde 34,2'si Microsoft Office, yüzde 28,8'i AdobePhotoshop, yüzde 9.6'sı Edius programlarını iyi bildiğini belirtmektedir. Uzmanlık gerektiren diğer tasarım ve kurgu programları araştırmaya katılanların çok azı tarafından kullanılabilmektedir. 
Tablo 15: Mesleğinizle ilgili katıldığınız kurslar, eğitimler, sertifikalar var mı?

\begin{tabular}{|l|c|c|}
\hline \multicolumn{3}{|c|}{ Mesleğinizle ilgili katıldığınız kurslar, eğitimler, sertifikalar? } \\
\hline & Sayı & $\%$ \\
\hline Evet & 25 & 34,2 \\
\hline Hayır & 48 & 65,8 \\
\hline Toplam & 73 & 100,0 \\
\hline
\end{tabular}

Tablo 16: Mesleğinizle ilgili aldığınız ödüller; var mı?

\begin{tabular}{|l|c|c|}
\hline \multicolumn{3}{|c|}{ Mesleğinizle ilgili aldı̆ıııı ödüller? } \\
\hline \multicolumn{3}{|c|}{} \\
\hline & Sayı & $\%$ \\
\hline Evet & 27 & 37,0 \\
\hline Hayır & 46 & 63,0 \\
\hline Toplam & 73 & 100,0 \\
\hline
\end{tabular}

Katılımcıların yüzde 65,8'inin meslekleriyle ilgili katıldıkları, kurs, eğitim ya da aldıkları bir sertifika bulunmamaktadır. Sadece yüzde 34,2'sinin mesleki yönden kendilerini geliştirecek meslekiçi eğitimler alabildiği görülmektedir. Katılımcıların yüzde 37'si mesleki ödül sahibidir.

Tablo 17: Üyesi olduğunuz sendika var mı?

\begin{tabular}{|l|c|c|}
\hline \multicolumn{3}{|c|}{ Üyesi olduğunuz sendika var mı? } \\
\hline & Sayı & $\%$ \\
\hline Evet & 9 & 12,3 \\
\hline Hayır & 64 & 87,7 \\
\hline Toplam & 73 & 100,0 \\
\hline
\end{tabular}

Tablo 18: Üye olduğunuz mesleki kurumlar var mı?

\begin{tabular}{|l|c|c|}
\hline \multicolumn{3}{|c|}{ Üye olduğunuz mesleki kurum-dernek var mı? } \\
\hline & Say1 & $\%$ \\
\hline Evet & 32 & 43,8 \\
\hline Hayır & 41 & 56,2 \\
\hline Toplam & 73 & 100,0 \\
\hline
\end{tabular}

Mesleki kurumlara üye olan gazetecilerin oranı yüzde 43,8 'dir. Sendikalı gazeteci oranı ise; yüzde 12,3'tür. Katılımcıların yüzde 87,7'sinin herhangi bir sendika üyeliği bulunmamaktadır. Yarıdan fazlası herhangi bir mesleki dernek ve cemiyete de üye değildir. Bu durum gazetecilerin örgütlenmede ne denli yetersiz kaldıklarını ortaya koymaktadır. Çalışma koşulları ve özlük haklarında ortaya çıkan olumsuzlukların büyük kısmı bu durumla ilişkilendirilebilinir. Sendika bir yana, çoğunluğu mesleki 
derneklere bile üye olmayan medya çalışanları her türlü zorluk ve zorlamaya daha açık konumdadır.

Tablo 19: Sigorta durumunuz

\begin{tabular}{|c|c|c|c|c|c|c|}
\hline \multicolumn{7}{|c|}{ Sigorta durumunuz } \\
\hline & \multicolumn{2}{|c|}{$\begin{array}{l}\text { a.Herhangi bir } \\
\text { sigortam yok }\end{array}$} & \multicolumn{2}{|c|}{$\begin{array}{l}\text { b. Normal İș Kanunu’na göre } \\
\text { sigortalıyım (4857 Sayılı İș Kanunu) }\end{array}$} & \multicolumn{2}{|c|}{$\begin{array}{l}\text { b.Basın İș Kanunu’na göre sigortalııım } \\
\text { (5953 Sayılı Basın İș Kanunu) }\end{array}$} \\
\hline & $S$ & $\%$ & $S$ & $\%$ & $S$ & $\%$ \\
\hline Evet & 2 & 2,7 & 15 & 20,5 & 51 & 69,9 \\
\hline Hayır & 71 & 97,3 & 58 & 79,5 & 22 & 30,1 \\
\hline Toplam & 73 & 100,0 & 73 & 100,0 & 73 & 100,0 \\
\hline
\end{tabular}

Katılımcı gazetecilerin yüzde 69,9'u 5953 Sayılı Basın İş Kanunu'na göre sigortalıyken; yüzde 20,5’i 4857 sayılı Normal İş Kanunu'na göre sigortalıdır. Bu noktada geçtiğimiz yıllara göre olumlu bir gelişme görülmektedir. Yasal olarak da gazeteci sıfatıyla çalışan ve bu haklardan yararlanabilen gazetecilerin oranı artmıştır.

Tablo 20: Yurt dışına çıktınız mı?

\begin{tabular}{|l|c|c|}
\hline \multicolumn{3}{|c|}{ Yurt dıșına çıktınız mı? } \\
\hline & S & $\%$ \\
\hline Evet & 30 & 41,1 \\
\hline Hayır & 43 & 58,9 \\
\hline Toplam & 73 & 100,0 \\
\hline
\end{tabular}

Katılımcı gazetecilerin sadece yüzde 41,1'i yurt dışına çıkmıştır. Dünyayı görme ve tanıma, mesleklerini icra ederken bu deneyimlerden yararlanma fırsatını çoğunluk henüz yakalayamamıştır.

Bu bölümde katılımcılara tutum ölçeği uygulanmıştır.

Tablo 21: Tutum ölçeği 1

\begin{tabular}{|c|c|c|c|c|c|c|c|c|c|c|c|c|c|c|}
\hline \multirow{2}{*}{$\begin{array}{l}\text { Antalya'da görev } \\
\text { yapan gazetecilerin } \\
\text { Avrupalı } \\
\text { meslektașlarından: }\end{array}$} & \multicolumn{2}{|c|}{$\begin{array}{l}\text { Tamamen } \\
\text { katillyorum }\end{array}$} & \multicolumn{2}{|c|}{ Katllyorum } & \multicolumn{2}{|c|}{ Kararsııım } & \multicolumn{2}{|c|}{ Katılmiyorum } & \multicolumn{2}{|c|}{$\begin{array}{l}\text { Hiç } \\
\text { katılmıyorum }\end{array}$} & \multicolumn{2}{|l|}{ Boș } & \multicolumn{2}{|c|}{ Toplam } \\
\hline & $S$ & $\%$ & $S$ & $\%$ & $S$ & $\%$ & $S$ & $\%$ & $S$ & $\%$ & $S$ & $\%$ & $S$ & $\%$ \\
\hline $\begin{array}{l}\text { 1.Yabancı dil eksiği } \\
\text { vardır }\end{array}$ & 56 & 76,7 & 14 & 19,2 & 0 & 0 & 1 & 1,4 & 0 & 0 & 2 & 2,7 & 73 & 100 \\
\hline 2.Eğitim eksiği vardır & 37 & 50,7 & 21 & 28,8 & 11 & 15,1 & 2 & 2,7 & 0 & 0 & 2 & 2,7 & 73 & 100 \\
\hline
\end{tabular}




\begin{tabular}{|l|l|l|l|l|l|l|l|l|l|l|l|l|l|l|}
\hline $\begin{array}{l}\text { 3.Bilgi-birikim eksiği } \\
\text { vardır }\end{array}$ & 28 & 38,4 & 19 & 26,0 & 14 & 19,2 & 7 & 9,6 & 1 & 1,4 & 4 & 5,5 & 73 & 100 \\
\hline $\begin{array}{l}\text { 4.Çalıșma șartları } \\
\text { ve özlük haklarında } \\
\text { eksiklikler vardı }\end{array}$ & 59 & 80,8 & 9 & 12,3 & 3 & 4,1 & 0 & 0 & 0 & 0 & 15 & 18,8 & 73 & 100 \\
\hline 5.Hiç̧̧ir eksiği yoktur & 1 & 1,4 & 0 & 0 & 2 & 2,7 & 13 & 17,8 & 47 & 64,4 & 10 & 13,7 & 73 & 100 \\
\hline
\end{tabular}

Gazeteciler, çalışma şartları ve özlük haklarında eksiklikler olduğu görüşüne tamamen katılmaktadır (yüzde 80,8 ). Bu sonuç daha önceki sorularda ortaya çıkan maaş miktarları ve çalışma saatleriyle örtüşmektedir.

Antalya'da görev yapan gazeteciler, Avrupalı meslektaşlarından en çok yabacı dil konusunda eksikliği olduğu görüşündedirler (yüzde 95,9). Bu cevap yabancı dil bilme oranı ile ilgili anket sorumuza bir özeleştiri niteliğinde değerlendirilebilir. Yüzde 79,5 'i de eğitim eksiği olduğu kanaatinde hemfikirdirler. Bilgi ve birikim eksiği olduğunu düşünenlerin oranı 64,4'tür. Katılımcıların yalnızca yüzde 1,4'ü Avrupalı meslektaşlarından hiçbir eksikliği olmadığı görüşündedir. Esasında bu veriler, gazetecilerin geniş anlamda bir özeleştirisi olarak okunmalıdır. Antalyalı gazetecilerin neredeyse yüzde 80'i eğitim eksiklerinin farkındadır ve bunu kabul etmektedir. Olumlu olarak görülebilecek taraf ise, bu farkındalığın ve kabullenişin gerçekleştirilebilecek doğru stratejiler ve eğitim faaliyetleriyle artıya çevrilebileceğidir.

Tablo 22: Tutum ölçeği 2

\begin{tabular}{|c|c|c|c|c|c|c|c|c|c|c|c|c|c|c|}
\hline \multirow[t]{2}{*}{ Genel Sorular } & \multicolumn{2}{|c|}{$\begin{array}{l}\text { Tamamen } \\
\text { katiliyorum }\end{array}$} & \multicolumn{2}{|c|}{ Katilıyorum } & \multicolumn{2}{|c|}{ Kararsızım } & \multicolumn{2}{|c|}{ Katılmıyorum } & \multicolumn{2}{|c|}{$\begin{array}{l}\text { Hiç } \\
\text { katılmıyorum }\end{array}$} & \multicolumn{2}{|c|}{ Boș } & \multicolumn{2}{|c|}{ Toplam } \\
\hline & $S$ & $\%$ & $S$ & $\%$ & $S$ & $\%$ & $S$ & $\%$ & $S$ & $\%$ & $S$ & $\%$ & $S$ & $\%$ \\
\hline $\begin{array}{l}\text { 1.Gazeteci olmak için } \\
\text { iletișim fakültesi } \\
\text { mezunu olmak } \\
\text { gerekli değildir }\end{array}$ & 26 & 35,6 & 20 & 27,4 & 12 & 16,4 & 13 & 17,8 & 2 & 2,7 & 0 & 0 & 73 & 100 \\
\hline $\begin{array}{l}\text { 2.Sektörde } \\
\text { iletișim fakültesi } \\
\text { mezunlarının sayısı } \\
\text { arttıkça mesleki } \\
\text { saygınlık artar }\end{array}$ & 14 & 19,2 & 25 & 34,2 & 16 & 21,9 & 11 & 15,1 & 5 & 6,8 & 2 & 2,7 & 73 & 100 \\
\hline $\begin{array}{l}\text { 3.Meslek içi } \\
\text { eğitimler yerel } \\
\text { medya çalıșanları } \\
\text { için gereklidir }\end{array}$ & 39 & 53,4 & 25 & 34,2 & 4 & 5,5 & 5 & 6,8 & 0 & 0 & 4 & 5,5 & 73 & 100 \\
\hline $\begin{array}{l}\text { 4.Ne kadar eğitim } \\
\text { alınısa alınsın } \\
\text { gazetecilik mesleği } \\
\text { sahada öğrenilir }\end{array}$ & 32 & 43,8 & 25 & 34,2 & 6 & 8,2 & 7 & 9,6 & 0 & 0 & 3 & 4,1 & 73 & 100 \\
\hline
\end{tabular}




\begin{tabular}{|l|l|l|l|l|l|l|l|l|l|l|l|l|l|l|}
\hline $\begin{array}{l}\text { 5.0̈zlük hakları } \\
\text { ve çalıșma } \\
\text { koșullarından } \\
\text { memnunum }\end{array}$ & 8 & 11,0 & 9 & 12,3 & 8 & 11,0 & 29 & 39,7 & 17 & 23,3 & 2 & 2,7 & 73 & 100 \\
\hline $\begin{array}{l}\text { 6.Dünyanın her } \\
\text { yerinde gazetecilik } \\
\text { yapabilecek bilgi, } \\
\text { birikim ve dile } \\
\text { sahibim }\end{array}$ & 4 & 5,5 & 7 & 9,6 & 15 & 20,5 & 39 & 53,9 & 6 & 8,2 & 2 & 2,7 & 73 & 100 \\
\hline $\begin{array}{l}7 . \text { Dünyaya tekrar } \\
\text { gelsem yine gazeteci } \\
\text { olurum }\end{array}$ & 26 & 35,6 & 8 & 11,0 & 23 & 31,5 & 4 & 5,5 & 10 & 13,7 & 2 & 2,7 & 73 & 100 \\
\hline
\end{tabular}

Gazetecilerin yüzde 87'6'sı meslekiçi eğitimlerin yerel medya çalışanları için gerekli olduğunu düşünmektedir. Buradan ise gazetecilerin eğitim eksiklerini gidermede istekli oldukları anlaşılmaktadır.

Katılımcıların yüzde 78'i ne kadar eğitim alınırsa alınsın gazetecilik mesleğinin sahada öğrenildiği görüşündedir. Katılımcıların yüzde 63'ü, gazeteci olmak için iletişim fakültesi mezunu olmanın gerekli olmadığı görüşündedir. Bu oran da yaklaşık olarak Antalya yerel medyasında iletişim fakültesi mezunu olmayan medya çalışanlarıyla aynıdır. Ancak diğer yandan sektörde iletişim fakültesi mezunlarının artmasının mesleki saygınlığı arttıracağını düşünenlerin oranı da dikkat değerdir (yüzde 53.4).

Katılımcıların yalnızca 23,3'ü çalışma şartları ve özlük haklarından memnundur. Daha büyük kısmı ise bu anlamda memnuniyetsizdir. Yine bu durum daha önceki sorularda ortaya koyduğumuz rakamlarla örtüşmektedir.

Araştırmaya katılanların yalnızca 15.1'i dünyanın her yerinde gazetecilik yapabilecek bilgi, birikim ve dile sahip olduğunu düşünmektedir. Diğer büyük kısım bu anlamda kendini yeterli görmemekte ve yerel ölçekte mesleği icra edebileceğini düşünmektedir. Tüm bu sorunlara karşın gazetecilik büyülü bir meslektir ve her şeye rağmen katılımcıların yüzde 46,6'sı tekrar dünyaya gelse yine bu mesleği yapmak isteyeceğini belirtmektedir. Gazeteciliğin mesleki hazzı ve toplumsal işlevi; tüm zorluklara rağmen mesleklerine bağlı çalışanları beraberinde getirmektedir.

\section{Sonuç}

YÖK'ün 2015 yılında yayınlandığı istatistiklere göre Türkiye'de üniversite mezunları içinde en yüksek işsizlik oranına sahip bölüm gazetecilik bölümü olmuştur. Diğer yandan Türk medyasının bugünkü durumu gerek basın özgürlüğü, gerek tekelleşme, gerek güç odaklarının etkileri, gerekse çalışma şartları ve özlük hakları yönünden oldukça sorunludur. Yerel medya kuruluşları ise tüm bu sorunlarla birlikte daha güç koşullarda yayın yapmaya gayret etmektedir. Yerel medya eleştirisi yapılırken, bu durum ve şartların da gözetilmesi gereklidir. 
Araştırma sonuçlarından görüleceği üzere Antalya yerel medyası çalışanları açısından ciddi bir eğitim eksikliği ve eğitim gerekliliği açık olarak ortaya çıkmıştır. Ayrıca bu eksiklik tekil olarak değerlendirilemez. Eğitim eksikliği özlük haklarından maaşlara, çalışma saatlerinden medya çalışanlarının saygınlıklarına kadar her düzeyde olumsuz gelişmelere neden olmaktadır. Tersinden bakıldığında ise çalışmada vurgulanan ekonomi-politik sorunlar bağlamında, yerel medya kuruluşlarının daha az eğitimli ve daha az vasıflı ve dolayısıyla daha az ücret ödenen çalışanları tercih ettiği şeklinde açıklanabilir.

Öte yandan yine Antalya yerel medya çalışanları bir özeleştiri olarak kendilerini yeterli görmemekte ve Avrupalı meslektaşlarından gerek eğitim, gerek bilgi ve birikim gerekse yabancı dil anlamında eksikleri olduğunu kabul etmekte ve dünya çapında gazetecilik yapamayacaklarını itiraf etmektedirler. Bu durumu olumsuz; bunun farkındalığını ise olumlu olarak yorumlamak mümkündür. Bu özeleştiri, yerel medya çalışanlarının kendilerini geliştirmek istediklerini göstermesi açısından önemlidir. Bu noktada kurumlara daha fazla görev düşmektedir. Eksiklerinin farkında olan ve bunları tamamlamayı isteyen çalışanlarının kendileri geliştirmeleri; dolayısıyla yerel medyayı geliştirmeleri için olanaklar yaratılmalıdır.

Sorunların bir nebze çözümü, iletişim fakülteleriyle iletişim sektörünün daha fazla birlikte hareket etmesi ve koordinasyonuyla mümkün olabilir. İletişim fakülteleri, neden mezunlarının bu kadar yüksek oranda işsiz kaldıklarını sorgulamalı ve çözüm yaratmak için çabalamalıdır. Medya kurumları ise bu kadar çok iletişim fakültesi mezunu olmasına rağmen, neden iletişim fakültesi mezunu olmayan daha ucuz ve daha vasıfsız işgücü çalıştırdığına cevap vermeli ve bugün medyada yaşanan birçok sorunun temelinde eğitim eksikliğinin de önemli bir yeri olduğunu kabullenmelidir. En önemli yatırım insana yapılan yatırımdır. Türk medyası geç de olsa bunu görmeli ve sıkıntıları bir nebze olsun hafifletmelidir.

Topluma daha fazla bilgi aktarabilen, temel işlevlerini yerine getirebilen bir Türk medyası ve öğrencilerine daha iyi eğitim veren, mezunlarına daha fazla olanak sağlayan iletişim fakültelerinin ancak bu şekilde mümkün olabileceği düşünülmektedir. Bunun ilk çıkış noktasının yerel medya olmaması için bir neden yoktur.

\section{Kaynakça}

Altun, Abdülrezzak (2005), “Yerel Medya Çalışanlarının Eğitim İhtiyacı ve Yerel Medya Enstitüsü”, İletişim Araştırmaları, 3 (1-2), 75-104.

Arslan, Erhan ve Arslan Berna (2016), "Türkiye'de Yerel Gazete Yöneticilerinin Meslek Etiği Algısı", Selçuk Iletişim Dergisi, 9 (2), 174-204.

Dağtaş, Erdal ve Banu, Dağtaş (2007), "Eskişehir Kent Basını ve Gazeteciliği Üzerine Bir Profil Denemesi: Gazetecilerin Kent Basınına İlişkin Tutumları", Galatasaray Üniversitesi İletişim Fakültesi Dergisi, Sayı: 6, İstanbul, 9-46.

Değirmencioğlu, Gürsoy (2011), "Yerel Basında Yeni Medya ve Sosyal Paylaşım Sitelerinin Kullanımı: Kocaeli'de Yayımlanan Yerel Gazetelerin İnternet Siteleri Üzerine Bir İnceleme",AJIT-e: Online Academic Journal of Information Technology, Vol: 2 /5, 19-31. 
Gezgin, Suat (2005). Türkiye'de Gazetecilik Eğitimi, http://www.konrad.org.tr/Medya\%20 tr/10suat.pdf, 04.05.2015.

Korkmaz, Ali (2012),“Gazetecilik Eğitimi Alan Öğrencilerin Gazetecilik Eğitimi ve Gazetecilik Mesleğine Bakışı”, Akdeniz İletişim Dergisi, No: 16, s. 9-27.

Temel, Mustafa, Korkmaz Ali, Somuncu Burak, Şilen Kenan (2012), "Yerel Medya Çalışanlarının Sosyo-Demografik Özellikleri ve Sektör Sorunlarına Bakışı: Kayseri ve Nevşehir Yerel Medyasına Yönelik Alan Araştırması", Mustafa Kemal Üniversitesi Sosyal Bilimler Enstitüsü Dergisi, 9 (19), s. 125-157.

Tokgöz, Oya (2003), “Türkiye'de İletişim Eğitimi: Elli Yıllık Bir Geçmişin Değerlendirilmesi”, Kültür ve Iletişim, No: 6(2), Sayfa: 7-32.

Toruk, İbrahim ve Emre O. Olkun (2014), "Ekonomi Politik Bağlamda Yaşanan Ak Parti-Cemaat Olaylarının Türk Basınına Yansımaları: Yeni Şafak, Star, Zaman, Bugün ve Milliyet Gazeteleri Örneği”, Selçuk Üniversitesi Türkiyat Araştırmaları Enstitüsü Dergisi, Sayı: 35, Konya, 377-400.

Ulusoy, Belkıs (2003), “Türkiye'de Yerel Basının Sorunları ve Çözüm Önerileri”, İstanbul Üniversitesi İletişim Fakültesi Dergisi, Sayı 18, 103-116.

Vural, Ali Murat (1996), "Yerel Kamuoyunun Kitle İletişim Aracı Olarak Yerel Basın”, Yeni Türkiye, 96/12, 1053-1067.

Yaşın, Cem (2009), “Türkiye'de Yerel Basının Yapısal Özellikleri ve Üretim Koşulları”, İletişim Fakültesi Dergisi, Sayı 28, 115-151.

Yıldırım, Besim (2006), “Eleştirel Pedagoji Açısından Gazetecilik Eğitimini Yeniden Düşünmek” / Re-Thinking of Journalism Education In Terms of Critical Pedagogy,http://dergiler.ankara.edu.tr/ dergiler/23/1816/19181.pdf), No: 4(1), 121-152.

Yılmaz, Nuray (2009), "Yerel Basının Etik Sorunları", İstanbul Üniversitesi İletişim Fakültesi Dergisi, Sayı 36, 131-143. 